\title{
LEARNING OBSTACLE KONSEP KOMBINASI PADA PEMBELAJARAN MATEMATIKA SEKOLAH MENENGAH ATAS
}

\author{
Rahmat Jumri ${ }^{1}$, Risnanosanti ${ }^{2}$ \\ ${ }^{1}$ Sekolah Tinggi Ilmu Tarbiyah Al-Quraniyah Manna, \\ ${ }^{2}$ Universitas Muhammadiyah Bengkulu \\ rahmatjumri@stit-alquraniyah.ac.id ${ }^{1}$
}

\begin{abstract}
Abstrak
Penelitian ini bertujuan untuk mengetahui learning obstacle terkait konsep kombinasi pada pembelajaran disekolah menengah atas. Penelitian ini merupakan penelitian deskripsi dengan pendekatan kualitatif. Untuk mengidentifikasi learning obstacle pada konsep kombinasi ini menggunakan tes kemampuan responden terdiri dari lima buah soal essay yang mengacu pada indikator pemahaman konsep. Subjek dalam penelitian ini adalah Siswa SMAN 1 Lebong Utara berjumlah 35 siswa dan mahasiswa FKIP matematika UMB berjumlah 14 orang. Hasil penelitian ini menunjukan bahwa terdapat empat tipe learning obstacle, yaitu : tipe 1 adalah learning obstacle terkait konsep kombinasi, tipe 2 adalah learning obstacle terkait concept image pada kombinasi, tipe 3 adalah learning obstacle terkait variasi informasi yang tersedia pada soal, tipe 4 adalah learning obstacle terkait dalam penyelesaian soal pemecahan masalah pada kombinasi.
\end{abstract}

Kata kunci : laerning obstacle, kombinasi, matematika.

\begin{abstract}
This research aims to determine the learning obstacle related to the concept of combination in high school learning. This research is a descriptive research with a qualitative approach. To identify learning obstacles in this combination concept, the respondent's ability test consists of five essay questions that refer to indicators of concept understanding. The subjects in this study were 35 students of SMAN 1 Lebong Utara and 14 students of FKIP Mathematics UMB. The results of this study indicate that there are four types of learning obstacles, namely: type 1 is a learning obstacle related to the concept of a combination, type 2 is a learning obstacle related to the concept image in a combination, type 3 is a learning obstacle related to the variation of information available on the question, type 4 is a learning obstacle. related obstacles in solving problem solving problems in combination.
\end{abstract}

Keywords: learning obstacle, combination, mathematics

\section{PENDAHULUAN}

Matematika merupakan ilmu yang universal yang mendasari perkembangan teknologi moderen. Matematika mempunyai peranan penting dalam berbagai disiplin ilmu sehingga memajukan daya pikir manusia untuk lebih baik. Penalaran dalam matematika mempunyai ciri-ciri yang tepat dan cocok untuk melatih kebiasaan bepikir manusia. Sebagai salah satu ilmu dasar yang memiliki nilai esensial sehingga dapat diterapkan dalam bidang kehidupan. Matematika juga dapat mengembangkan daya nalar sebagai bekal utama dalam mengembangkan dirinya dalam mencapai keberhasilan.
Menurut Brousseau (1997) proses pembelajaran merupakan suatu proses membangun kemandirian melalui suatu perwujudan dan hak siswa untuk belajar. Dalam pelaksanaanya siswa berhak mendapatkan hak belajar untuk berpikir,brpendapat dan bertanya Oleh karena itu siswa juga memiliki hak untuk menciptakan situasi belajar dengan kondisi yang dimilikinya atau yang diingkannya. Namun kenyataan yang terjadi di lapangan secara alamiah siswa masih banyak mengalami suatu situasi yang disebut kesulitan dalam belajar atau hambatan belajar (learning obstacle).

Dalam penelitian ini learning obstacle hanya terfokus kepada hambatan 
epistimologisnya. Hambatan epistimologis adalah hambatan pembelajaran yang muncul karena keterbatasan seseorang dalam memahami suatu materi hanya pada konteks tertentu saja. Pada saat siswa diberikan soal dengan konteks yang lain siswa tidak dapat mengerjakan, bahkan kebingungan, itulah muncul kesulitan pada saat belajar (learning obstacles) dalam memahami suatu materi. Hambatn epistimologis pertama kali dekenalkan pada tahun 1983 oleh seorang filsuf Perancis yang bernama Gaston Bachelard yang ada dalam artikelnya La formation de l'esprit scientifique. Menurut Bachelard hambatan epistimologis adalah kondisi yang disyaratkan oleh kemunculan setiap pengetahuan baru. Suatu pengetahuan dikatakan baru apabila ia berhasil merumuskan masalahnya sendiri terlepas dari perumusan masalah sebelumnya. Begitu masalah yang akan dijawab berubah, maka terjadilah hambatan epistimologis.

Matematika memiliki peranan penting dalam segala bidang. Dengan adanya matematika semua ilmu pengetahuan menjadi lebih sempurna. Tanpa ada matematika semuanya dapat mengalami hambatan (Soedjadi, 2000). Pendapat ini juga didukung oleh Mulyono (2003) yang menyatakan bahwa matematika mempunyai peranan penting dalam pendidikan, maka pemerintah menetapkan matematika sebagai bidang studi yang wajib dipelajari dari tingkat Sekolah Dasar, Sekolah Menengah Pertama, dan Sekolah Menengah Atas, sampai Perguruan Tinggi.

Murdiana, Jumri \& Damara (2020) mengatakan pembelajaran matematika di lapangan menunjukkan sebagian besar kegiatan pembelajaran matematika memprioritaskan pelajar sebagai objek.Berdasarkan pembelajaran matematika yang dilakukan disekolah, guru cenderung menyampaikan materi seperti apa yang ada dalam buku panduan yang digunakan sehingga adanya konsep yang terbatas dari materi tersebut

atau ada konsep yang tidak tersampaikan kepada siswa. Guru sebagai ujung tombak pembelajaran bisa memberikan suatu informasi yang lebih dalam peroses pembelajaran, supaya materi yang didapat siswa itu tidak terbatas dan pengetahuan siswa menjadi lebih luas dan hendaknya guru itu tidak memberikan pengetahuan yang ada dalam bahan ajar saja, supaya siswa bias memilih menggunakan cara mana yang lebih muda dipahaminya dan dimengertinya.

Salah satu konsep yang cukup penting dalam matematika adalah konsep peluang. Konsep peluang dipelajari siswa pada tingkat Sekolah Menengah Pertama (SMA), bahkan diperguruan tinggi pun bagi mahasiswa yang mengambil bidang keahlian matematika, dipelajari secara lebih mendalam. Peluang merupakan konsep dasar matematika yang sering digunakan dalam berbagai cabang ilmu pengetahuan lain seperti ilmu geografi. Sehingga peluang adalah salah satu konsep yang penting dan perlu dipahami secara benar. Kombinasi merupakan bagian dari konsep peluang. keterkaitan antra konsep - konsep yang ada dala peluang sangat erat, menjadikan beberapa hal perlu diketahui siswa sebelum dia mempelajari konsep kombinasi diantaranya siswa harus memahami terlebih dahulu aturan pengisian tempat, permutasi. Apabila konsep-konsep awal belum dipahami, sudah dipastikan siswa tidak mampu memahami konsep tersebut.

Menurut Herman Hudojo dalam Mubarik (2013) mempelajari konsep B yang mendasarkan pada konsep A seseorang terlebih dahulu harus memahami konsep A. Oleh karena itu penguasaan konsep yang utuh sangat diperlukan di setiap tahap pembelajaran matematika. Penguasaan konsep yang tidak utuh nantinya dapat menimbulkan hambatan belajar (learning obstacle). Proses pembelajaran merupakan suatu proses membangun kemandirian melalui suatu perwujudan dan hak siswa untuk belajar. Dalam pelaksanaanya siswa berhak mendapatkan hak belajar untuk berpikir,berpendapat dan bertanya Oleh karena itu siswa juga memiliki hak untuk menciptakan situasi belajar dengan kondisi yang dimilikinya atau yang diinginkannya. Namun kenyataan yang terjadi di lapangan secara alamiah siswa masih banyak mengalami suatu situasi yang disebut 
kesulitan dalam belajar atau hambatan belajar (learning obstacle).

Setiap siswa memiliki peluang untuk mengalami kesulitan atau mendapat hambatan belajar, yang dimaksud hambatan yang dialami siswa waktu proses belajar berlangsung saat penyampaian konsep apapun yang diberikan oleh guru. Salah satunya adalah konsep kombinasi. Materi peluang ini berguna sekali dalam kehidupan kita sehari - hari dan membantu kita dalam mengetahui peluang - peluang yang ada dalam kehidupan ini. Konsep ini sangat dibutuhkan dikehidupan kita sekarang ini supaya kita bisa membedakan setiap peluang yang muncul.

Dalam penelitian ini learning obstacle hanya terfokus kepada hambatan epistimologisnya. Hambatan epistimologis adalah hambatan pembelajaran yang muncul karena keterbatasan seseorang dalam memahami suatu materi hanya pada konteks tertentu saja. Pada saat siswa diberikan soal dengan konteks yang lain siswa tidak dapat mengerjakan, bahkan kebingungan, sehingga muncul kesulitan pada saat belajar (learning obstacles) dalam memahami suatu materi. Mengenai permasalahan tersebut, maka penelitian ini akan membahas menenai learning obstacle yang terjadi pada konsep kombinasi. Tujuan dari penelitian ini adalah utnuk mengetahui learning obstacle yang terdapat pada konsep kombinasi.

\section{METODE}

Metode penelitian yang digunakan adalah metode deskriptif dengan pendekatan kualitatif. Alat pengumpulan data yang digunakan yaitu instrumen soal konsep kombinasi, lembar wawancara semistruktur. Tes diberikan pada subjek yang telah belajar konsep kombinasi di sekolah menengah atas. Data yang diperoleh adalah lembar jawaban siswa dan hasil wawancara terhadap sebagian responden dan guru matematika. Penelitian ini akan dilakukan di SMA Negeri 1 Lebong Utara Kabupaten Lebong Provinsi Bengkulu dan Mahasiswa Universitas Muhammadiyah Bengkulu Fakultas Keguruan dan Ilmu Pendidikan Jurusan Matematika. Subjek dalam penelitian ini yaitu subjek untuk mencari learning obstacle. Subjek yang digunakan untuk mencari learning obstacle adalah siswa SMAN 1 Lebong Utara berjumlah 35 siswa dan mahasiswa FKIP matematika UMB berjumlah 14 orang. Subjek penelitian dalam hal ini diambil secara acak dari berbagai tingkatan yaitu siswa dan mahasiswa yang telah mendapatkan pembelajaran Kombinasi di sekolah.

\section{HASIL PENELITIAN DAN PEMBAHASAN}

Learning Obstacle dalam penelitian ini diperoleh dari jawaban responden dalam menjawab soal konsep Kombinasi. Instrumen yang digunakan untuk mengetahui learning obstacle pada konsep ini adalah lima butir soal esay yang masingmasing soal memiliki indikator pembelajaran dan indikator pemahaman konsep matematika. Learning obstacle kemudian dikategorikan berdasarkan pengertian leraning obstacle oleh Broseau (1997) yang menyatakan bahwa terdapat tiga hambatan belajar yaitu hambatan ontogenik, hambatan didaktis dan hambatan epistemologis. Dalam penelitian ini learning obstacle yang ditemukan adalah learning obstacle epistemologis.

Menurut Brousseau (1997) hambatan epistemologis adalah hambatan belajar yang dialami siswa pada penyelesaian masalah yang diajukan dilihat dari sudut pandang karakteristik learning obstacle, maka jenis hambatan yang muncul pada tes kemampuan responden yang telah dilakukan lebih bersifat epistemologis. Hambatan epistemologis adalah hambatan seseorang terkait pengetahuannya yang hanya terbatas pada konteks tertentu. Jika diberikan konteks yang berbeda dia mengalami kesulitan untuk menggunakan pengetahuan yang dimilikinya. Ada beberapa tipe dalam hambatan yang telah ditemukan, tipe ini digunakan untuk merancang desain sehinggga mempermudah dalam meminimalkan hambatan yang terjadi. Adapun tipenya antara lain :
1. Learning Obstacle Terkait
Pengertian Konsep Kombinasi 
Learning obstacle seperti ini terjadi karena banyak responden yang tidak memahami pengertian konsep kombinasi yang sebnarnya. Hal ini terbukti dari hasil tes kemampuan responden dan hasil wawancara responden, yang mana responden tidak bisa menyebutkan atau memahami konsep kombinasi itu seperti apa yang sebenarnya. Responden hanya menghafal kata kunci dari kombinasi yaitu urutannya tidak diperhatikan, sehingga dalam menentukan penggunaan yang dilakukaan dalam sebuah peristiwa responden masih salah.

Responden yang menghafal kata kunci membuat mereka tidak bisa menyelsaikan soal. Bruner menyarankan dalam Dahar (2006) agar siswa- siswa hendaknyan belajar melalui partisipasi secara aktif dengan konsep dan prinsip-prinsip agar mereka dianjurkan untuk memperoleh pengalaman dan melakukan eksperimen-eksperimen sehingga mereka bisa utnuk menemukan prinsipprinsip itu sendiri. Responden memahami konsep kombinasi dengan benar bukan sekedar mengtahui kata kunci dari kombinasi itu. Learning obstacle tipe ini terdapat pada soal 1 dan 2.

2. Learning Obstacle Terkait Concept Image Pada Kombinasi

Learning obstacle tipe ini terjadi dikarenakan responden benar mengerjakan soal kalau soal tersebut menggunakan gamabar. Ketika soal tidak menggunakan gamabar responden tidak bisa mengerjakanya. Artinya responden paham ketika mereka melihat soal dan mereka juga bisa menyebutkan permintaan soal tersebut dengan melihat gamabar. Hal seperti ini menyebabkan responden tidak bisa menerima soal yang tidak menggunakan gambar, mereka tidak bisa menyelsaikan dengan tepat. Pada konsep kombinasi siswa bisa menyelesaikan dan dapat membedakan permutasi dan kombinasi dengan menggunakan gamabar. Learning obstacle tipe ini terjadi pada soal nomor 3, yang mana soal tersebut menggunakan gamabar dan responden diminta menjlaskan dari gambar tersebut.

\section{Learning Obstacle Terkait Variasi Informasi yang Tersedia Pada \\ Kombinasi}

Learning obstacle seperti ini disebabkan adanya variasi informasi soal yang berbeda, sehingga siswa tidak bisa memahami maksud dari soal tersebut. Responden mengalami kesulitan untuk memahami informasi yang ada didalam soal tersebut, ketika soal sudah membingungkan atau soal sudah mempunyai variasi informasi responden tidak bisa menyelsaikan masalah yang terdapat didalam soal tersebut. Responden hanya mengerjakan soal sesuai dengan informasi yang mereka punya. Mereka tidak mengembangkan informasi yang mereka ketahui.

Menurut teori Ausubel dalam Dahar (2006), belajar yang relevan adalah belajar bermakna. Belajar bermakna merupakan suatu proses yang dikaitan dengan informasi baru pada konsep-konsep yang relevan yang terdapat dalam struktur kognitif seseorang. Seorang siswa memiliki pengetahuan yang lama kemudian informasi lama tersebut digunakan dalam mengembangkan konsep yang baru. Sehingga informasi tersebut bisa menambah wawasan siswa. Learning obstacle tipe ini terdapat pada soal nomor 4.

Learning obstacle terkait penyelesaian soal pemecahan masalah ini terjadi karena responden tidak bisa menyelsaikan masalah yang ada dalam soal secara benar, mereka tidak bisa memecahkan masalah yang terdapat dalam soal. Responden mengerjakan soal dengan tidak memahami apa yang harus dipecahkan dalam soal tersebut. Untuk konsep kombinasi responden tidak bisa menyelesaikan soal dengan pemecahan masalah, jawaban dari responden hanya sekedar benar menggunakan rumus, tetapi mereka tidak memcahkan masalah apa yang seharusnya mereka selsaikan dalam soal tersebut.

Learning obstacle untuk konsep kombinasi diperoleh dari hasil analisis tes kemampuan responden yang telah dikerjakan oleh responden dan pengetahuan siswa terhadap konsep kombinasi yang 
diperoleh dari hasil wawancara, sehingga diperoleh empat tipe learning obstacle yaitu:

1. Learning obstacle terkait konsep kombinasi

Learning obstacle terkait konsep kombinasi ini disebabkan karena responden tidak bisa mengerjakan soal dengan benar ketika diberikan konteks yang berbeda, mereka terpaku pada satu konteks saja. Responden tidak memahami konsep kombinasi sehinnga mereka salah dalam menjawab walaupun benar menjawab tetapi tidak sesuai dengan konsep yang sebenarnya. Hambatan jenis ini termasuk kedalam hambatan epistemologis, karena kemampuan pemahaman siswa pada konsep kombinasi terbatas pada kata kunci urutan diperhatikan atau tidak. Hal ini yang menyebabkan siswa tidak mampu menyelesaikan persoalan jika kata kunci tersebut digantikan dengan maksud yang sama. Hal ini terbukti dari hasil wawancara responden tidak menjawab ketika diberi pertanyaan mengenai pengertian perbandingan trigonometri.

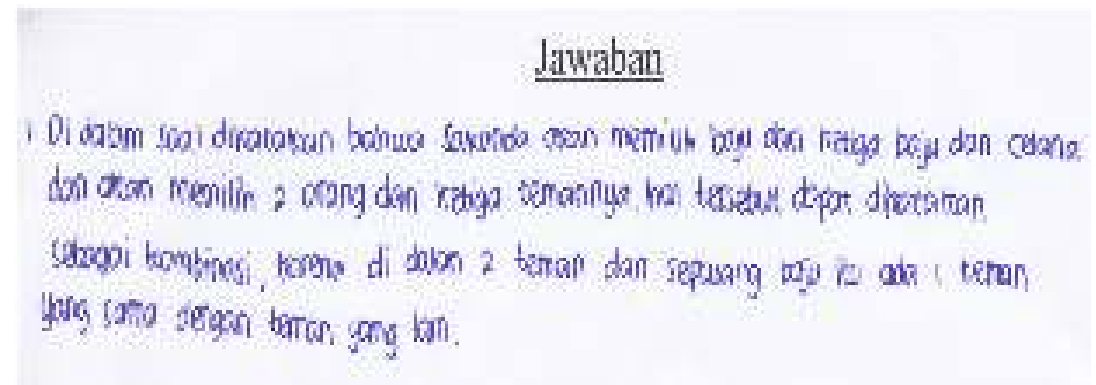

Gambar 1. Learning obstacle tipe 1

\begin{abstract}
Berdasarkan hasil jawaban tes kemampuan responden yang telah dikerjakan oleh responden dan diperkuat dengan wawancara sebagai berikut :
\end{abstract}

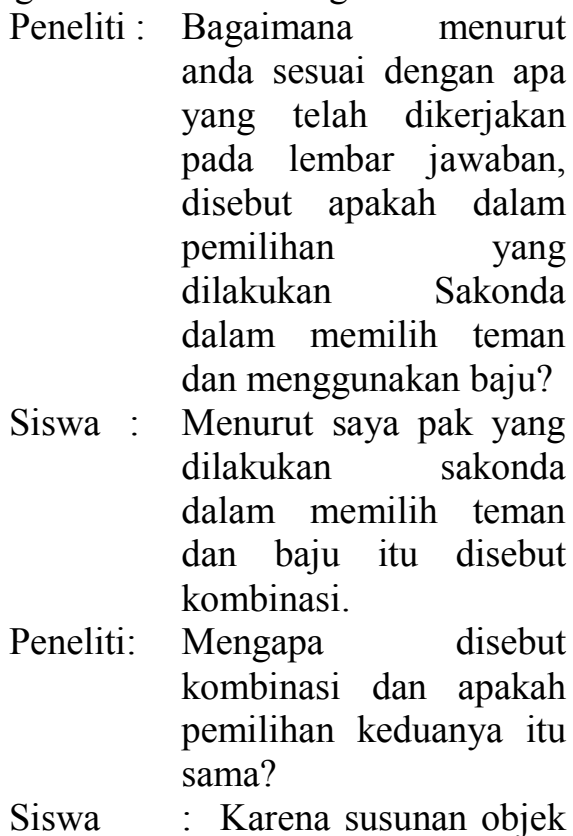

tidak diperhatikan dan pemilihan keduanya itu sama

2. Learning obstacle terkait concept image pada kombinasi

Learning obstacle terkait concept image pada kombinasi ini terjadi dikarenakan responden benar mengerjakan soal kalau soal tersebut menggunakan gamabar. Ketika soal tidak menggunakan gambar responden tidak bisa mengerjakanya. Artinya responden paham ketika mereka melihat soal dan mereka juga bisa menyebutkan permintaan soal tersebut dengan melihat gambar. Hal seperti ini menyebabkan responden tidak bisa menerima soal yang tidak menggunakan gambar, mereka tidak bisa menyelsaikan dengan tepat. Pada konsep kombinasi siswa bisa menyelesaikan dan dapat membedakan permutasi dan kombinasi dengan menggunakan gamabar. 


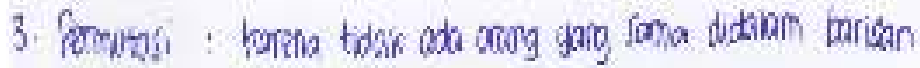

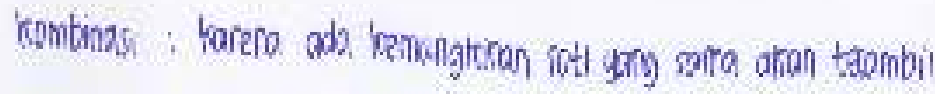

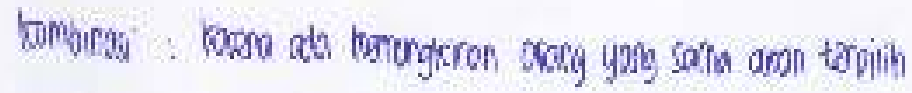

Gambar 2. Learning obstacle tipe 2

\begin{abstract}
Berdasarkan hasil jawaban tes kemampuan responden yang telah dikerjakan oleh responden dan diperkuat dengan wawancara sebagai berikut :
\end{abstract}

Peneliti :Perhatikan gambar-gambarnya, merupakan masalah apa yang terjadi pada gamabar tersubut?

Siswa : Menurut saya pak yang masalah yang terjadi dilahat dari gambar ini adalah gambar pertama permutasi, gambar kedua kombinasi, dan gambar ketiga kombinasi.

Peneliti: Bisa dijelaskan mengapa menjawab seperti itu nak ?

Siswa : Untuk gambar pertama pada saat orang berbaris posisi orang tersebut diperhatikan urutanya, utuk yang kedua dan ketiga itu urutan tidak diperhatikan pak.

Peneliti : Begitu ya, ini bisa membedakanya kalau menggunakan gambar padahal soal ini bentuknya juga sama dengan yang pertama dan kedua, kenapa soal pertama tidak bisa?

Siswa :ya kalau menggunakan gambar lebih mudah saja untuk membedakan dan mengerjakannya pak.

3. Learning obstacle terkait variasi informasi yang tersedia pada kombinasi

Learning obstacle terkait variasi informasi yang tersedia pada kombinasi ini disebabkan adanya variasi informasi soal yang berbeda, sehingga siswa tidak bisa memahami maksud dari soal tersebut. Responden mengalami kesulitan untuk memahami informasi yang ada didalam soal tersebut, ketika soal sudah membingungkan atau soal sudah mempunyai variasi informasi responden tidak bisa menyelsaikan masalah yang terdapat didalam soal tersebut. Responden hanya mengerjakan soal sesuai dengan informasi yang mereka punya. Responden Mereka tidak mengembangkan informasi yang mereka ketahui.

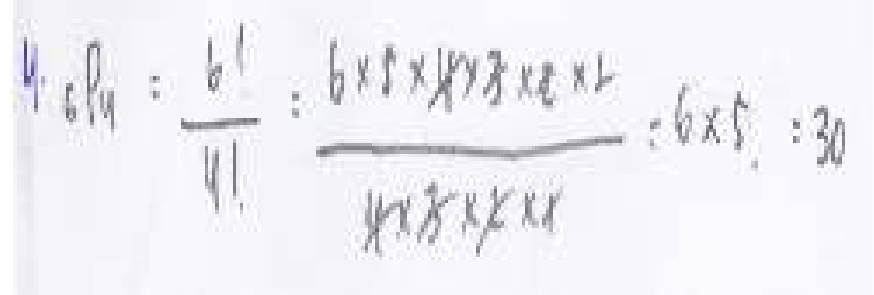

Gambar 3. learning obstacle tipe 3

Berdasarkan hasil jawaban tes kemampuan responden yang telah dikerjakan oleh responden dan diperkuat dengan wawancara sebagai berikut :

Peneliti: Apakah permintaan dari soal tersebut?
Siswa: Menurut saya pak soal nomor empat ini adalah cara Rianki untuk membuat makanan ayam itu ada berapa macam.

Peneliti: Emangnya ada berapa macam makanan yang dibuat oleh 


\section{Rianki!}

Siswa: $\quad$ Ada 30 macam pak.

Peneliti: Ada 30 macam ya, itu menggunakan cara apa!

Siswa: Cara yang digunakan yaitu menggunkan permutasi.

Peneliti: Oh, menggunakan cara permutasi mengapa menggunakan permutasi kenapa tidak kombinasi yang digunakan!

Siswa: (siswa bingung dan tidak menjawab)

4. Learning obstacle terkait dalam penyelesaian soal pemecahan masalah pada kombinasi

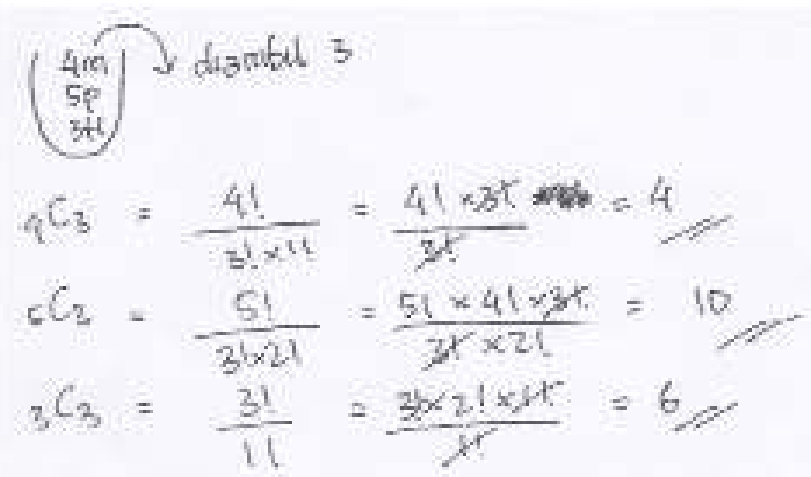

Gambar 4. learning obstacle tipe 4

Berdasarkan hasil jawaban tes kemampuan responden yang telah dikerjakan oleh responden dan diperkuat dengan wawancara sebagai berikut :

Peneliti: Apa permintaan dari soal tersebut?

Ssiswa: Permintaan soal ini adalah untuk mengetahui berapa banyak cara yang dilakukan Egy untuk mengambil kelereng dalam sebuah kotak.

Peneliti: Ada berapa cara yang dapat dilakukan Egy untuk mengambil kelereng!

Siswa: Ada 20 cara

Peneliti: Ada 20 cara ya, itu menggunakan cara apa, bisa dijelaskan pengerjaanya bagaimana!

Siswa: Cara yang digunakan yaitu menggunkan kombinasi, dikerjakan satu-satu, pertama 4 kombinasi 3 setelah dapat
Learning obstacles terkait penyelesaian soal pemecahan masalah ini terjadi karena responden tidak bisa menyelesaikan masalah yang ada dalam soal secara benar, mereka tidak bisa memecahkan masalah yang terdapat dalam soal. Responden mengerjakan soal dengan tidak memahami apa yang harus dipecahkan dalam soal tersebut. Untuk konsep kombinasi responden tidak bisa menyelesaikan soal dengan pemecahan masalah, jawaban dari responden hanya sekedar benar menggunakan rumus, tetapi mereka tidak memcahkan masalah apa yang seharusnya mereka selsaikan dalam soal tersebut. 
mengalami kesulitan untuk menggunakan pengetahuan yang dimilikinya. Berdasarkan penelitian yang telah dilakukan dapat dinyatakan bahwa siswa mengalami learning obstacle dalam mempelajari konsep kombinasi. keempat tipe tersebut merupakan hambatan epistemologis dimana responden tidak bisa mengerjakan soal jika konteksnya berbeda, mereka hanya terpaku pada konteks tertentu. Sehingga dapat disimpulkan bahwa konsep kombinasi yang dipelajarinya tidak tertanam dengan baik dalam ingatanya.

Didasarkan pada tujuan matematika untuk SMA dan pada tahap perkembangan intelektual siswa SMA yang semestinya sudah berada pada tingkat operasional formal. Pada tingkat operasional foromal ini anak dapat menggunakan operasi-operasi konkretnya untuk membentuk operasi yang lebih kompleks.

Namun pada kenyataan ini responden yang terdiri dari siswa SMA dan mahasiswa belum bisa menggunakan operasi-operasi konkritnya untuk membentuk suatu operasi yang lebih kompleks. Responden tidak dapat menerapkan pengetahuan yang mereka miliki, responden hanya terpaku pada konteks tertentu dan responden belum memahami konsep kombinasi yang sebenarnya itu seperti apa.

Menurut teori Ausubel dalam Ratna Wilis Dahar (2011), belajar yang relevan adalah belajar bermakna. Belajar bermakna merupakan suatu proses yang dikaitan dengan informasi baru pada konsep-konsep yang relevan yang terdapat dalam struktur kognitif seseorang. Misalnya seorang siswa memiliki pengetahuan yang lama kemudian informasi lama tersebut digunakan dalam mengembangkan konsep yang baru.

\section{SIMPULAN}

Dalam mempelajari konsep kombinasi responden banyak mengalami hambatan, hal ini Berdasarkan hasil penelitian yang diperoleh dari hasil Tes Kemampuan Responden yang telah diberikan kepada siswa-siswi SMA dan mahasiswa adalah orang yang telah menerima materi Peluang pada sub pokok bahasan kombinasi. Dapat disimpulkan bahwa terdapat hambatan dalam mengerjakan soal yang telah diberikan. Hambatan yang muncul ada 4 tipe, Keempat tipe termasuk kedalam hambatan epistimologis, hambatan ini terjadi akibat keterbatasan siswa pada konteks tertentu saja. Hambatan epistemologis terjadi saat seseorang diberikan suatu konteks yang berbeda, dia mengalami kesulitan untuk menggunakan pengetahuan yang dimilikinya. Dalam hal ini pandangan siswa terhadap konsep yang lain terputus-putus dan tidak komprehensif. Responden tidak dapat menggunakan pengetahuan terdahulunya dan mengembangkan pengetahun yang dimilikinya untuk dapat diterapkasn dalam belajar konsep kombinasi. Responden yang terdiri dari siswa SMA dan mahasiswa belum dapat mencapai tingkat perkembangan intelektual pada tahap operasional formal. Kekuranganya informasi menyebabkan responden tidak dapat menyelesaikan pemecahan masalah dalam sebuah soal.

\section{REFERENSI}

Brousseau, G. (1997). Theori Of Didactical Situation In Mathematics. Dordrecht: Klawer Academic Publisher Group.

Dahar, R. W. (2011). Teori-Teor Belajar Dan Pembelajaran. Bandung: Erlangga.

Mubarik. (2013). Profil Pemecahan Masalah Siswa Auditorial Kelas X SLTA pada Materi Sistem Persamaan Linear Dua Variabel. Jurnal Elektronik Pendidikan Matematika Tadulako. Di Akses Tanggal 02 Februari 2013 dari http://portalgaruda.org/?ref=browse\&mo $\mathrm{d}=$ viewarticle\&article $=111562$

Mulyono, A. (2003). Pendidikan Bagi Anak Kesulitan Belajar. Jakarta : Rineka Cipta.

Murdiana, M., Jumri, R., Damara, B.E.P. (2020). Pengembangan Kreativitas Guru dalam Pembelajaran Matematika. Jurnal Pendidikan Matematika Raflesia, Vol 5, No 2, Hal 152-160.

Soedjadi. (2000). Kiat Pendidikan Matematika Di Indonesia Kontatasi Keadaan Masa Kini Menuju Harapan Masa Depan.Jakarta: Depdiknas. 